\title{
KAJIAN EFEKTIFITAS DAN IMPLEMENTASI PENGgUNAAN APLIKASI Berbasis Open Source untuK Pembelajaran Pada Sekolah Menengah atas
}

\author{
${ }^{1}$ Ismu Prihanto, ${ }^{2}$ Rudi Hermawan, dan ${ }^{3}$ Harry Dhika \\ ${ }^{1,2,3}$ Program Studi Teknik Informatika, Fakultas Teknik, Matematika dan Ilmu Pengetahuan Alam, \\ Universitas Indraprasta PGRI Jakarta \\ email : ${ }^{\text {ismu80@yahoo.co.id, }}{ }^{2}$ rh001unindra@gmail.com, ${ }^{3}$ dhikatr@yahoo.com
}

\begin{abstract}
Abstrak. Perkembangan Teknologi Informasi Komunikasi saat ini sudah sangat pesat, tidak terkecuali perkembangan TIK di bidang pendidikan. Perkembangan TIK ini di tanggapi oleh pemerintah dalam hal ini Kementerian Pendidikan Nasional Republik Indonesia dengan memasukkanTIK kedalam mata pelajaran wajib. Pemerintah melalui Kemdiknas pernah mencanangkan sebuah program IGOS (Indonesia Go Open Source). Program IGOS dicanangkan karena maraknya penggunaan software ilegal di Indonesia. Pemerintah mencoba membangun solusi dengan mencanangkan program IGOS melalui dunia pendidikan diharapkan Indonesia bisa membangun Sumber Daya Manusia yang mempunyai kemampuan di bidang IT dengan menggunakan aplikasi opensource tanpa harus membajak. Namun di sisi lain, kurikulum TIK yang diberikan kepada sekolah masih mengacu software proprietary. Pembelajaran Open Source di sekolah juga banyak menemui kendala dari kesiapan pihak sekolah. Banyaknya anggapan Open Source itu sulit sudah sangat melekat di masyarakat kita tidak terkecuali di dunia pendidikan. Rendahnya tingkat penerimaan dan penggunaan open source di sekolah lebih disebabkan karena rendahnya kebutuhan dan tuntutan siswa pada penggunaan open source dan persepsi siswa dan guru TIK di sekolah pada open source yang masih minim. Dan Kurang aktifnya peran pemerintah dalam mendukung dan menjalankan program IGOS dilingkungan sekolah memberikan kontribusi terhadap lambannya proses pembelajaran open source di sekolah.
\end{abstract}

Kata kunci : TIK, IGOS, open source, software propietary

\section{Pendahuluan}

Perkembangan Teknologi Informasi dan komunikasi saat ini sudah sangat pesat sekali. Pemerintah melalui Kementrian Pendidikan Nasional Republik Indonesia (Kemendiknas) telah mengantisipasi dengan memasukkan Tekonologi Informasi dan Komunikasi (TIK) sebagai mata pelajaran wajib disekolah. Namun disayangkan kurikulum pembelajaran TIK masih mengacu kepada Sistem operasi dan Software yang berbayar. Dan buku mata pelajaran yang beredar di pasaran mayoritas masih mengacu kepada salah satu produk software berbayar tersebut. Hanya sedikit sekali buku yang mengacu kepada Open Source.

Open Source merupakan sebuah sistem terbuka yang dalam mendistribusikan software kepada pengguna dengan memberikan program dan source code nya secara gratis. Bahkan pengguna dapat mempelajari dan melakukan modifikasi untuk membuat software tersebut sesuai dengan kebutuhan mereka. Richard M. Stallman,pendiri Free Software Foundation sebuah organisasi yang mendukung Open Source,mengeluarkan sebuah lisensi software untuk Open Source yang dinamakan GPL (GNU Public License). Lisensi inilah yang saat ini paling banyak digunakan untuk mendistribusikan 
software Open Source. Selain GPL, masih banyak lisensi software lainnya yang dikembangkan oleh komunitas Open Source. Linux adalah sebuah contoh open source yang bagus. Banyak sistem operasi yang berusaha meniru kisah sukses Linux, tetapi Linux tetap yang paling sukses hingga saat ini. Aspek positif dari Open Source adalah penerimaan yang luas untuk software yang benar-benar bagus.

\section{Tinjauan Pustaka}

Definisi open source sudah cukup banyak sekali dan saat ini sudah sangat akrab di kenal selain difinisi tersebut diatas juga kita mengenal istilah non open source, limited open source, limited open source dan kita juga mengenal organisasi open source. Dari istilah diatas secara umum kita bisa menyimpulkan bahwa Non open source adalah penggunaan source secara komersial dengan pembayaran royalti yang mahal atas lisensi dari source tersebut. Limited open source merupakan pemakaian source secara terbatas berdasarkan penyajian penyewaan terbatas dengan pembayaran sewa yang relatif murah atas source tersebut. Full open source adalah pemakaian source secara bebas dimana source tersebut termasuk source milik publikatau organisasi open source atau yang kita kenal dengan free software foundation. Dan yang terakhir istilah orgaisasi open source adalah sebuah organisasi yang menangani open source, misalnya GNU Project. Disamping itu masih banyak ostilah lain yang berkaintan dengan open source seperti yayasan free open soure, free software dan tentunya seluruhnya diatur dalam UU Hak ciptaNo. 19. Th. 2002 yang mengatur properti film dan komputer.

Linux (diucapkan linəks atau linuks)[1] adalah nama yang diberikan kepada sistem operasi komputer bertipe Unix. Linux merupakan salah satu contoh hasil pengembangan perangkat lunak bebas dan sumber terbuka utama. Seperti perangkat lunak bebas dan sumber terbuka lainnya pada umumnya, kode sumber Linux dapat dimodifikasi, digunakan dan didistribusikan kembali secara bebas oleh siapa saja. Nama "Linux" berasal dari nama pembuatnya, yang diperkenalkan tahun 1991 oleh Linus Torvalds. Sistemnya, peralatan sistem dan pustakanya umumnya berasal dari sistem operasi GNU, yang diumumkan tahun 1983 oleh Richard Stallman. Kontribusi GNU adalah dasar dari munculnya nama alternatif GNU/Linux. (wikipedia)

\section{Metode Penelitian}

Penelitian ini merupakan penelitian explanatory research atau confirmatory research, penelitian yang berusaha menjelaskan hubungan kausal antara variabelvariabel yang diamati dan diteliti melalui pengujian hipotesis yang telah dirumuskan. Penelitian ini dilakukan untuk membuktikan hipotesis yang dibangun dengan melakukan survei langsung. Dengan metode ini, dalam penelitian ini akan dilakukan analisa kajian terhadap faktor-faktor yang mempengaruhi penerimaan penggunaan sistem berbasis Open Source pada seluruh komponen di lingkungan sekolah.

\section{Studi Pustaka}

Studi kepustakaan bertujuan untuk mempelajari dan memahami dasar teori yang berhubungan dengan analisa kebutuhan yang telah dilakukan. Pengumpulan data dilakukan dengan mencari dan mendapatkan data secara teoritis melalui literaturliteratur, jurnal penelitian, bahan kuliah, dan sumber lainnya dari internet yang berhubungan dengan materi kajian penerimaan sistem informasi/teknologi informasi. 


\section{Kuesioner}

Pelaksanaan kuisioner dimaksudkan untuk mendapatkan data yang dibutuhkan dalam penelitian. Kuisioner bersifat closed question yang berupa pertanyaan-pertanyaan yang telah dibuat atau disusun. Kuisioner ini mempunyai tujuan untuk mendapatkan gambaran dari Responden tentang bagaimana penerimaan sistem berbasis Open Source di sekolah, dan bagaimana pola pembelajaran dan penerapan dalam penggunaan Aplikasi Open Source.

Data yang didapatkan dari survey dengan membagikan kuesioner akan dianalisis dengan metode statistik multivariat, diolah dengan menggunakan software statistik.

Dari kajian teori dan pengamatan yang telah dilakukan oleh peneliti, maka faktor-faktor tersebut antara lain adalah : 1) pemahaman dan pengetahuan (persepsi) tentang Open Source, 2) Kebutuhan dan tuntutan siswa, 3) Daya dukung sekolah, dan 4) Kemampuan sumber daya manusia di sekolah. Faktor-faktor tersebut didefinisikan sebagai variabel bebas (independent variable), sedangkan variabel terikatnya adalah penerimaan penggunaan sistem berbasis Open Source.

\section{Teknik Analisa data}

\subsection{Statistik Deskriptif}

Dalam analisis deskriptif akan dilakukan teknik penyajian data dalam bentuk tabel disitribusi frekwensi, grafik/diagram batang untuk masing-masing variabel. Selain itu juga masing-masing variabel akan diolah dan dianalisis ukuran pemusatan dan letak seperti mean, modus, dan median serta ukuran simpangan seperti jangkauan, variansi, simpangan baku, kemencengan dan kurtosis.

\subsection{Uji Persyaratan Analisis Data}

\subsubsection{Uji Normalitas}

Uji normalitas bertujuan untuk mengetahui apakah data hasil pengumpulan berdistribusi normal atau tidak. Hal ini akan berpengaruh pada proses lanjutan analisis statistik, jika data berdistribusi normal, maka analisis dilanjutkan menggunakan statistik parametrik, sedangkan jika data tidak berdistribusi normal, maka analisis dilanjutkan menggunakan statistik non parametrik. Uji normalitas dalam penelitian ini dilakukan dengan menggunakan analisis Kolmogorov Smirnov dalam program aplikasi komputer untuk statistik, yaitu SPSS 17.0. Hasil perhitungan dan pengujian dengan SPSS 17.0 ditunjukkan oleh tabel Tests of Normality pada kolom Sig untuk pengujian teknik Kolmogorov Smirnov Kriterian kenormalannya adalah adalah jika nilai sig KS > 0,05 maka data tersebut dikatakan berdistribusi normal.

\subsubsection{Uji Linieritas Garis Regresi}

Pengujian linieritas garis regresi digunakan bantuan program SPSS 17.0, yaitu dengan melihat besarnya nilai koefisien sig pada baris Deviation from Liniearity dari tabel Anova yang dihasilkan oleh progam SPSS pada pengujian linieritas garis regresi ini.

Kriteria pengujian linieritasnya adalah sebagai berikut: jika sig $>0,05$ maka garis regresi tersebut linier dan, jika sig $\leq 0,05$ maka garis regresi tersebut tidak linier 


\section{A. Pengujian Pengaruh Variabel Bebas terhadap Variabel Terikat}

Setelah keseluruhan uji persyaratan analisis data dipenuhi dan diketahui data layak untuk diolah lebih lanjut, maka langkah berikutnya adalah menguji masingmasing hipotesis yang telah diajukan. Pengujian hipotesis menggunakan teknik korelasi partial dan korelasi ganda, serta regresi linier sederhana dan regresi linier ganda.

Dalam prakteknya, untuk perhitungan dan pengujian korelasi dan regresi baik partial maupun ganda akan digunakan bantuan program SPSS 17.0. Adapun kriteria pengujiannya adalah sebagai berikut :

a. Analisis Korelasi

1) Perhitungan dan Pengujian Signifikansi Koefisien Korelasi Partial

Hasil perhitungan koefisien korelasi partial bisa dilihat dari output program SPSS melalui analisis korelasi yakni pada tabel Correlations. Perhitungan dan Pengujian Signifikansi Koefisien Korelasi Ganda

Hasil perhitungan koefisien korelasi ganda bisa dilihat dari output program SPSS melalui analisis regresi yakni pada tabel Model Summary ${ }^{\mathbf{b}}$. Signifikasi dari koefisien korelasi tersebut diuji secara manual atau dengan bantuan komputer melalui program aplikasi Microsoft Excel.

\section{b. Analisis Regresi}

1) Perhitungan Persamaan Garis Regresi

Hasil perhitungan garis regresi bisa dilihat dari output program SPSS melalui analisis regresi yakni pada tabel Coefficients ${ }^{\mathbf{a}}$. Koefisien-koefisien persamaan garis regresi ditunjukkan oleh bilangan-bilangan yang ada pada kolom B untuk Unstandardized Coefficients.

Untuk pengaruh partial setiap variabel bebas $\mathrm{X}$ terhadap variabel bebas $\mathrm{Y}$ persamaan regresinya adalah $\hat{Y}=a_{0}+a_{1} x$

Sedangkan untuk pengaruh ganda semua variabel bebas $\mathrm{X}_{1}, \mathrm{X}_{2}, \mathrm{X}_{2}$, dan $\mathrm{X}_{4}$ terhadap variabel bebas $Y$ maka persamaan regresinya adalah $\hat{Y}=a_{0}+a_{1} x_{1}+a_{2} x_{2}+a_{3} x_{3}+a_{4} x_{4}$

2) Pengujian Signifikansi Regresi

Hasil pengujian signifikansi regresi bisa dilihat dari output program SPSS melalui analisis regresi yakni pada tabel ANOVA ${ }^{\mathbf{b}}$ kolom $\mathbf{F}$ atau Sig.

Kriteria signifikansinya adalah :

- Jika digunakan Kolom Sig, maka kriteria signifikansinya adalah :

"jika Sig < 0,05 maka garis regresi tersebut signifikan"

- Jika digunakan Kolom F, maka kriteria signifikansinya adalah : "jika $F_{\text {hitung }}>F_{\text {tabel }}$ maka garis regresi tersebut signifikan"

$\boldsymbol{F}_{\text {tabel }}$ dipilih sesuai dengan ketentuan pengujian statistik pada distribusi F, yaitu pada taraf nyata $\alpha$ derajat ( $\mathrm{dk}$ ) pembilang $=\mathrm{k}$ dan derajat $(\mathrm{dk})$ penyebut $=\mathrm{n}-\mathrm{k}-$ 1 , dimana $\mathrm{n}$ adalah banyaknya anggota sampel dan $\mathrm{k}$ adalah banyaknya variabel bebas.

\section{B. Hasil Penelitian}

1. Analisa menurut rata-rata skor per butir pertanyaan

Berdasarkan nilai rata-rata skor per butir pertanyaan maka variabel dengan ratarata skor per butir pertanyaan paling rendah adalah vaiabel kebutuhan dan tuntutan siswa yaitu sebesar 2,09 atau 41,7\% dari skor maksimum, hal ini berarti bahwa tuntutan 
dan kebutuhan siswa pada penggunaan linux dan open source sangat rendah. Terendah beikutnya adalah varibel persepsi pada open source yaitu sebesar 2,38 atau 47,68\% dari skor maksimum, hal ini berarti bahwa persepsi responden pada linux dan open source juga cukup rendah.

Untuk variabel kemampuan SDM rata-rata skor per butir pertanyaan adalah sebesar 2,614 atau 52,28\% dari skor maksimum, yang berarti lebih bahwa kemampuan responden pada penggunaan linux dan open source cukup tinggi. Sedangkan rata-rata skor per butir pertanyaan paling tinggi adalah variabel daya dukung sekolah, yaitu sebesar 3,66 atau 73,14\% dari skor maksimum, yang berarti bahwa daya dukung managemen sekolah terhadap pengggaunaan linux dan open source sangat tinggi.

Untuk variabel terikat yaitu penerimaan penggunaan linux dan open source, ratarata skor per butir pertanyaan sebesar 2,903 atau 58,07\% dari skor maksimum. Hal ini menunjukkan bahwa penerimaan responden untuk menggunakan linux dan open source cukup tinggi. Data data di atas bisa disimpulkan bahwa kurangnya penerimaan sekolah pada penggunaan linux dan open source lebih disebabkan rendahnya kebutuhan dan tuntutan siswa pada pengetahuan dan penggunaan linux dan open source, serta rendahnya persepsi sekolah pada linux open souce.

\section{Analisa menurut persentase keberagaman jawaban responden}

Pesentase keberagaman dalam hal ini menunjukkan tingkat keberagaman jawaban responden atas angket yang diberikan oleh peneliti. Dari hasil perhitungan terlihat bahwa tingkat keberagaman jawaban responden atas angket yang diberikan oleh peneliti yang paling rendah adalah variabel daya dukung sekolah yaitu sebesar $16,63 \%$, hal ini menunjukkan bahwa daya dukung sekolah pada penggunaan linux dan open source tidak banyak beragam, atau hampir sama di setiap sekolah.

Sedangkan untuk variabel yang lain, tingkat keberagaman jawaban responden atas angket yang diberikan oleh peneliti hampir sama yaitu sekitar $25 \%$, hal ini berarti kondisi variabel-variabel tesebut (persepsi pada open source, kebutuhan dan tuntutan siswa pada open source, kemampuan SDM pada open source, dan tingkat penerimaan dan penggunaan open source) sangat beragam di setiap sekolah.

\section{Pengujian Persyaratan Analisis}

Pengujian persyaratan analisis data yang dilakukan dalam penelitian ini adalah pengujian normalitas, homogenitas, dan linieritas garis regresi partial antara variabel bebas dan variabel terikat.

\section{Pengujian Normalitas Data}

Pengujian normalitas data masing-masing sampel diuji melalui hipotesis berikut:

$\mathrm{H}_{0}$ : data pada sampel tersebut berdistribusi normal

$\mathrm{H}_{1}$ : data pada sampel tersebut tidak berdistribusi normal

Perhitungan dilakukan dengan bantuan komputer melalui program aplikasi SPSS 17. Menurut ketentuan yang ada pada program tersebut maka kriteria dari normalitas data adalah "jika $p$ value ( $\mathrm{sig})>0.05$ maka $\mathrm{H}_{0}$ diterima", yang berarti data pada sampel tersebut berdistribusi normal. Nilai $p$ value (sig) adalah bilangan yang tertera pada kolom sig dalam hasil/output perhitungan pengujian normalitas oleh program SPSS. Dalam hal ini digunakan metode Kolmogorov-Smirnov. Pengujian Linieritas Garis Regresi 
Pengujian linieritas dalam penelitian ini digunakan hipotesis berikut : $\mathrm{H}_{0}$ : garis regresi hubungan antara varibel $\mathrm{X}$ dan variabel $\mathrm{Y}$ linier $\mathrm{H}_{1}$ : garis regresi hubungan antara varibel $\mathrm{X}$ dan variabel $\mathrm{Y}$ tidak linier

Perhitungan dilakukan dengan bantuan komputer melalui program aplikasi SPSS 17. Menurut ketentuan yang ada pada program tersebut maka kriteria dari normalitas data adalah "jika $p$ value (sig) $<0.05$ maka $\mathrm{H}_{0}$ diterima", yang berarti bahwa sampelsampel tersebut berasal dari populasi yang homogen. Nilai $p$ value (sig) adalah bilangan yang tertera pada kolom sig baris Linierity dalam ANOVA hasil perhitungan pengujian linieritas garis regresi oleh program SPSS. Semua pengaruh variabel bebas $X$ terhadap variabel terikat $Y$ lebih besar dari 0,05 , sehingga $\mathrm{H}_{0}$ diterima, dengan kata lain bahwa semua garis regresi yang tebentuk dari pengaruh variabel bebas $X$ terhadap variabel terikat $Y$ tersebut linier.

\section{Pengujian Hipotesis}

\section{Analisa Korelasi dan Deteminasi}

a. Korelasi Partial

Koefisien korelasi yang terbentuk dari masing-masing pengaruh variabel $\mathrm{X}$ terhadap variabel terikat $\mathrm{Y}$ secara partial signifikan pada taraf nyata $1 \%$, hal ini menunjukkan bahwa masing-masing variabel bebas $X$ tersebut (persepsi pada open source, kebutuhan dan tuntutan siswa pada open source, daya dukung sekolah, dan kemampuan SDM pada open source) secara signifikan berpengaruh secara partial terhadap terikat Y (Tingkat Penggunaan Open Source).

\section{b. Korelasi Ganda}

Koefisien korelasi ganda semua variabel bebas $X$ secara bersama-sama terhadap variabel terikat $Y$ adalah sebesar 0,812 , dan signifikan pada taraf nyata $1 \%$, yang berarti bahwa memang ada pengaruh semua variabel bebas $\mathrm{X}$ (persepsi pada open source, kebutuhan dan tuntutan siswa pada open source, daya dukung sekolah, dan kemampuan SDM pada open source) secara signifikan berpengaruh secara bersama-sama terhadap terikat Y (Tingkat Penggunaan Open Source).

\section{Analisa Regresi}

Dari hasil pengujiannya diperoleh nilai $\mathbf{F}_{\text {hitung }}$ yang semunya lebih besar dari $\mathbf{F}_{\text {tabel }}$, dimana nilai $\mathbf{F}_{\text {tabel }}$ untuk n (banyaknya data) $=50$, $\mathrm{k}$ (banyaknya variabel bebas) $=1$, dan taraf nyata $=5 \%$ adalah 4,04 . Demikian juga jika perhatikan nilai Sig, semuanya kurang dari 0,05 .

Hal tersebut berarti bahwa untuk hipotesis 1 s.d. $4, \mathrm{H}_{0}$ ditolak dan $\mathrm{H}_{1}$ diterima, dengan kata lain bahwa memang terdapat pengaruh yang signifikan masing-masing vaiabel bebas $\mathrm{X}$ (persepsi pada open source, kebutuhan dan tuntutan siswa pada open source, daya dukung sekolah, dan kemampuan SDM pada open source) secara partial terhadap variabel terikat Y (Tingkat Penggunaan Open Source).

Dari analisa regresi tersebut dapat disimpulkan bahwa semua variabel bebas $\mathrm{X}$ (persepsi pada open source, kebutuhan dan tuntutan siswa pada open source, daya dukung sekolah, dan kemampuan SDM pada open source) masing-masing berpengaruh positif dan signifikan secara partial terhadap variabel terikat Y (Tingkat Penggunaan Open Source). 


\section{a. Regresi Ganda}

Dari hasil pengujiannya diperoleh nilai $\mathbf{F}_{\text {hitung }}=21.842$ lebih besar dari $\mathbf{F}_{\text {tabel }}$, dimana nilai $\mathbf{F}_{\text {tabel }}$ untuk n (banyaknya data) $=50$, k (banyaknya variabel bebas $)=4$, dan taraf nyata $=5 \%$ adalah 5,57. Demikian juga jika perhatikan nilai Sig, semuanya kurang dari 0,05 .

Hal tersebut berarti untuk hipotesis $5, \mathrm{H}_{0}$ ditolak dan $\mathrm{H}_{1}$ diterima, dengan kata lain bahwa memang terdapat pengaruh yang signifikan semua vaiabel bebas $\mathrm{X}$ (persepsi pada open source, kebutuhan dan tuntutan siswa pada open source, daya dukung sekolah, dan kemampuan SDM pada open source) secara bersama-sama terhadap variabel terikat Y (Tingkat Penggunaan Open Source).

Dari analisa regresi tersebut dapat disimpulkan bahwa semua variabel bebas (persepsi pada open source, kebutuhan dan tuntutan siswa pada open source, daya dukung sekolah, dan kemampuan SDM pada open source) semua berpengaruh positif dan signifikan secara bersama-sama terhadap variabel terikat Y (Tingkat Penggunaan Open Source).

\section{Kesimpulan}

Berdasarkan deskripsi data penelitian dan setelah dilakukan analisis serta pengujian maka dapat disimpulkan :

1) Terdapat pengaruh yang positif dan signifikan semua variabel bebas $X$ (persepsi pada open source, kebutuhan dan tuntutan siswa pada open source, daya dukung sekolah, dan kemampuan SDM pada open source) terhadap variabel terikat Y (Tingkat Penggunaan Open Source) baik secara partial maupun secara bersamasama.

2) Rendahnya tingkat penerimaan dan penggunaan open source di sekolah khususnya untuk pembelajaran TIK (58.07\%) lebih disebabkan karena rendahnya kebutuhan dan tuntutan siswa pada penggunaan open source $(41.70 \%)$ dan rendahnya persepsi siswa dan guru TIK di sekolah pada open source (47.68\%).

3) Rendahnya kebutuhan dan tuntutan siswa pada penggunaan open source lebih dikarenakan kurangnya penggunaan open source di dunia kerja baik sektor pemerintah maupun sektor swasta, sehingga merasa kawatir jikalau kemampuan, ketrampilan, dan pengetahuannya tentang open source tidak terserap di dunia kerja.

4) Rendahnya persepsi siswa dan guru TIK serta para pengelola sekolah pada open source lebih disebabkan kurangnya aktifnya pemerintah dalam mendukung dan menjalankan program IGOS (Indonesia Go Open Source) dilingkungan sekolah.

5) Daya dukung sekolah dan kemampuan SDM di sekolah sangat memungkinkan untuk meningkatkan penerimaan dan penggunaan open souce di sekolah baik untuk pembelajaran TIK maupun untuk kegiatan administrasi sekolah.

\section{Saran}

berikut :

Saran yang bisa penulis sampaikan pada kesempatan ini adalah sebagai

1) Hendaknya pemerintah lebih gencar dalam mensosialisasikan program gerakan penggunaan open source (Indonesia Go to Open Source = IGOS) ke berbagai sektor, baik kepada instansi peerintah maupun swasta, terlebih lagi kepada komunitas pendidikan. 
2) Hendaknya semua instansi baik pemerintah maupun swasta turut berpatisipasi aktif untuk mendukung program pemerintah yaitu IGOS tersebut, yaitu dengan penerapan penggunaan open source untuk kegiatan administrasi di kantornya.

3) Hendaknya sekolah turut berpatisipasi aktif untuk mendukung program pemerintah yaitu IGOS tersebut, yaitu dengan penerapan penggunaan open source untuk pembelajaran TIK, maupun untuk kegiatan administrasi sekolah

4) Hendaknya pada guru mata pelajaran TIK di sekolah meningkatkan kemampuannya khususnya pada program-program sistem operasi maupun program aplikasi berbasis open source.

5) Hendaknya para siswa berpatisipasi aktif untuk mendukung program IGOS tersebut, yaitu dengan lebih mempelajari program-program sistem operasi maupun program aplikasi berbasis open source.

\section{Daftar Pustaka}

Pengembangan Open Source Software Indonesia 2025, Grand Scenario OSS Indonesia 2010-2014

SPSS Programming and Data Management, 3rd Edition

Stallings, W. (2001). Operating Systems , 4th edition, Prentice Hall

Tanenbaum, A. S.(2001). Modern Operating Systems, 2nd edition, Prentice Hall.

www.ilmukomputer.com

www.inherent-dikti.net/files/sisdiknas.pdf tanggal akses 20 september 2012 jam 13.00

www.jurnalonline.com

www.wikipedia.com

http://id.wikibooks.org/wiki/Pure IGOS tanggal akses 19 september 2012 jam 21.19. 